\title{
Response of soybean varieties to maturity and biomass production under various planting dates
}

\author{
Asim Muhammad ${ }^{1 *}$, Shad Khan Khalil ${ }^{1}$, Amir Zaman Khan ${ }^{1}$ and Nisar \\ $\mathrm{Ahmad}^{2}$ \\ 1. Department of Agronomy, Faculty of Crop production Sciences, The University of Agriculture Peshawar, \\ Pakistan \\ 2. Department of Biotechnology, University of Science \& Technology of Bannu, Pakistan \\ *Corresponding author's email: asimmuh@aup.edu.pk
}

Citation

Asim Muhammad, Shad Khan Khalil, Amir Zaman Khan and Nisar Ahmad. Response of soybean varieties to maturity and biomass production under various planting dates. Pure and Applied Biology. Vol. 5, Issue 3, pp418425. http://dx.doi.org/10.19045/bspab.2016.50054

\begin{tabular}{llll}
\hline \hline Received: 14/11/2015 & Revised: 12/05/2016 & Accepted: 16/062016 & Onirst: 28/06/2016
\end{tabular}

Abstract

Planting date plays a significant role in soybean maturity and biomass yield. To study the maturity and biomass production potential under different environmental conditions, three indigenous land races (Kulat brown, Kulat white, Mothi) and two improved varieties (NARC-II, Swat-84) of soybean were planted at monthly from April to July during 2004 and 2005 growing season, at New Developmental Farm, The University of Agricultural Peshawar, Pakistan. Data was recorded for full maturity, plant height and biomass production. April planted crop took maximum days (187) to maturity, which decreased gradually with delay in planting. May planted crop gave maximum plant height $(91.4 \mathrm{~cm})$ and biomass yield $\left(12598 \mathrm{~kg} \mathrm{ha}^{-1}\right)$ which decreased in later planting. Kulat white took maximum days (170) to maturity and attained maximum plant height $(107 \mathrm{~cm})$. However maximum biomass $12606 \mathrm{~kg} \mathrm{ha}^{-1}$ yield was given by Mothi. Landraces took 41 days more than improved varieties to mature. In land races the plant height was almost double and the biomass yield was 31 percent higher than the improved varieties. Land races could prove higher yielders if the extra biomass production is directed towards seed filling.

Keywords: Planting dates; Maturity; Biomass; Soybean land races

\section{Introduction}

In soybean [Glycine max (L.) Merrill] grain yield is the product of dry matter accumulation and partitioning. Greater total dry matter results in greater seed yield [1]. Overproduction of vegetative dry matter does not always reduce seed yields, but improve partitioning of dry weight could result in higher seed yields [2, 3]. Planting date, the most critically important environmental factor influencing soybean development and production [4]. Several workers have reported substantial reduction in days to maturity with delayed planting [5, 6]. Similar reduction in plant height with late planting [7-9]. Long duration soybeans were high biomass producers than short duration soybeans [6]. When planting was delayed from optimum time, substantial reduction in biomass yield was observed 
$[10,11]$. Based on the hypothesis of the above workers, it was considered essential to explore and compare. The biomass production potential of land races and improved verities of soybean under different planting dates.

\section{Materials and method}

Plant materials and experimental design

Research was conducted on maturity, plant height and biomass production of three land races (Kulat brown, Kulat White, Mothi) and two improved varieties (NARC-II, Swat-84) of soybean at New Developmental Farm, The University Agricultural Peshawar, Pakistan, during 2004 and 2005. Seeds were sowed at four planting dates. Planting dates were allotted to main while varieties were allotted to sub plots. Each treatment was replicated four times in randomized complete block design with split plot arrangement. Twenty seedlings per meter row were maintained with $5 \mathrm{~cm}$ space between the plants and $50 \mathrm{~cm}$ apart rows. As the field was already under soybean last year, therefore a starter dose of $25 \mathrm{~kg} \mathrm{~N}$ and $64 \mathrm{~kg} \mathrm{P}_{2} \mathrm{O}_{5} \mathrm{ha}^{-1}$ as DAP was applied at the time of sowing.

\section{Data collection}

In each subplot two central rows were harvested to determine biomass yield. The harvested material was dried in oven at 70 ${ }^{0} \mathrm{C}$ for 24 hours till constant weight. The dry biomass yield thus obtained was converted into $\mathrm{Kg} \mathrm{ha}^{-1}$. The stage when most of the leaves turned yellow, desiccated, and 95 percent of the pods lost green colour and attained mature pod colour, as full maturity (R8). Plant height data was recorded by measuring height of ten randomly selected plants in each subplot from the base to the top of the main stem at maturity.

\section{Statistical analysis}

The data was subject to analysis of variance technique appropriate for randomized complete block design with split plot treatment arrangement. When the $\mathrm{F}$ value was significant, means were compared using LSD test at 0.05 level of probability [12].

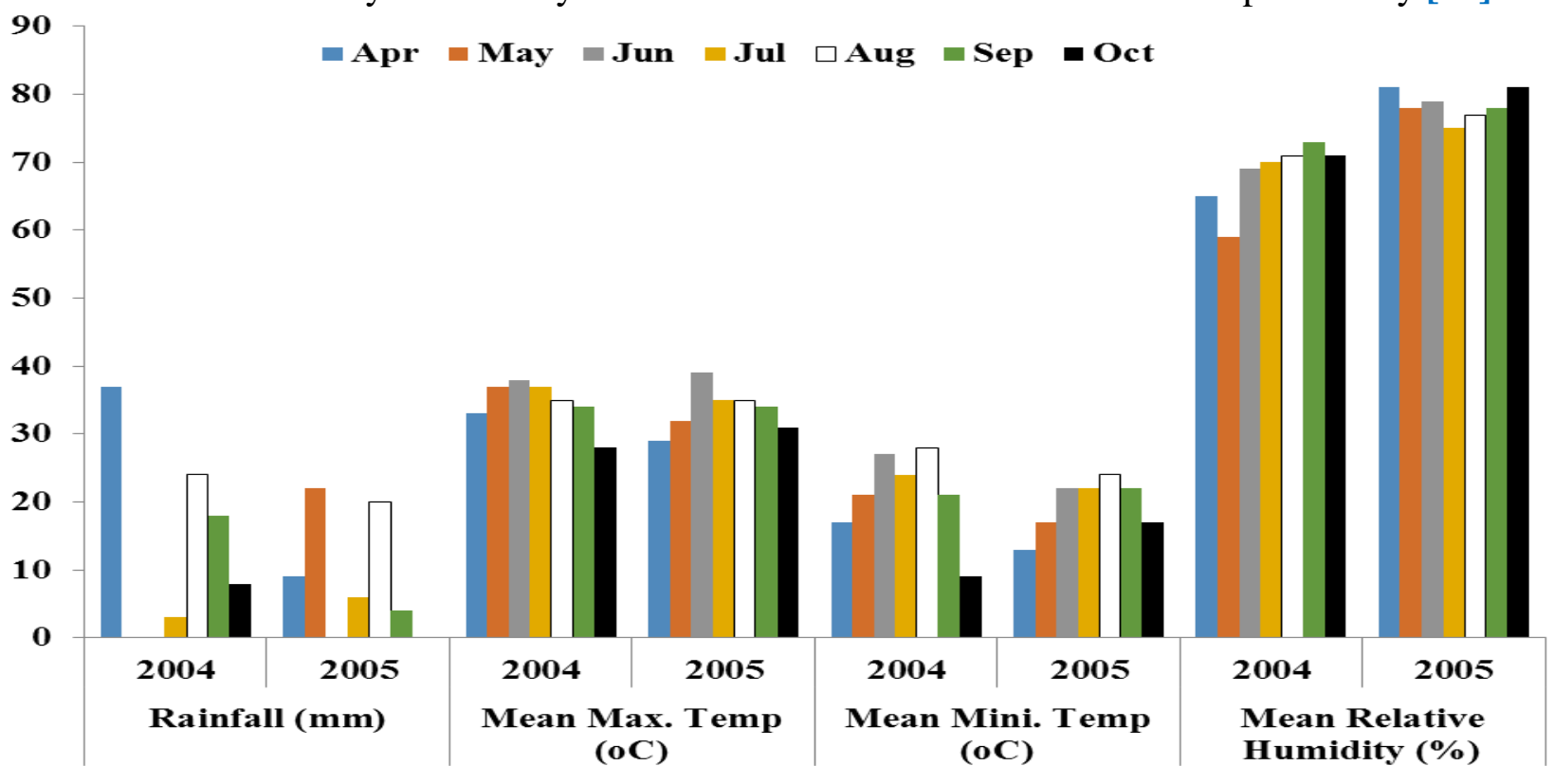

Figure 1. Mean monthly rainfall $(\mathrm{mm})$, minimum \& maximum temperature $\left({ }^{\circ} \mathrm{C}\right)$ and relative humidity (\%) of the experimental site during 2004-2005 


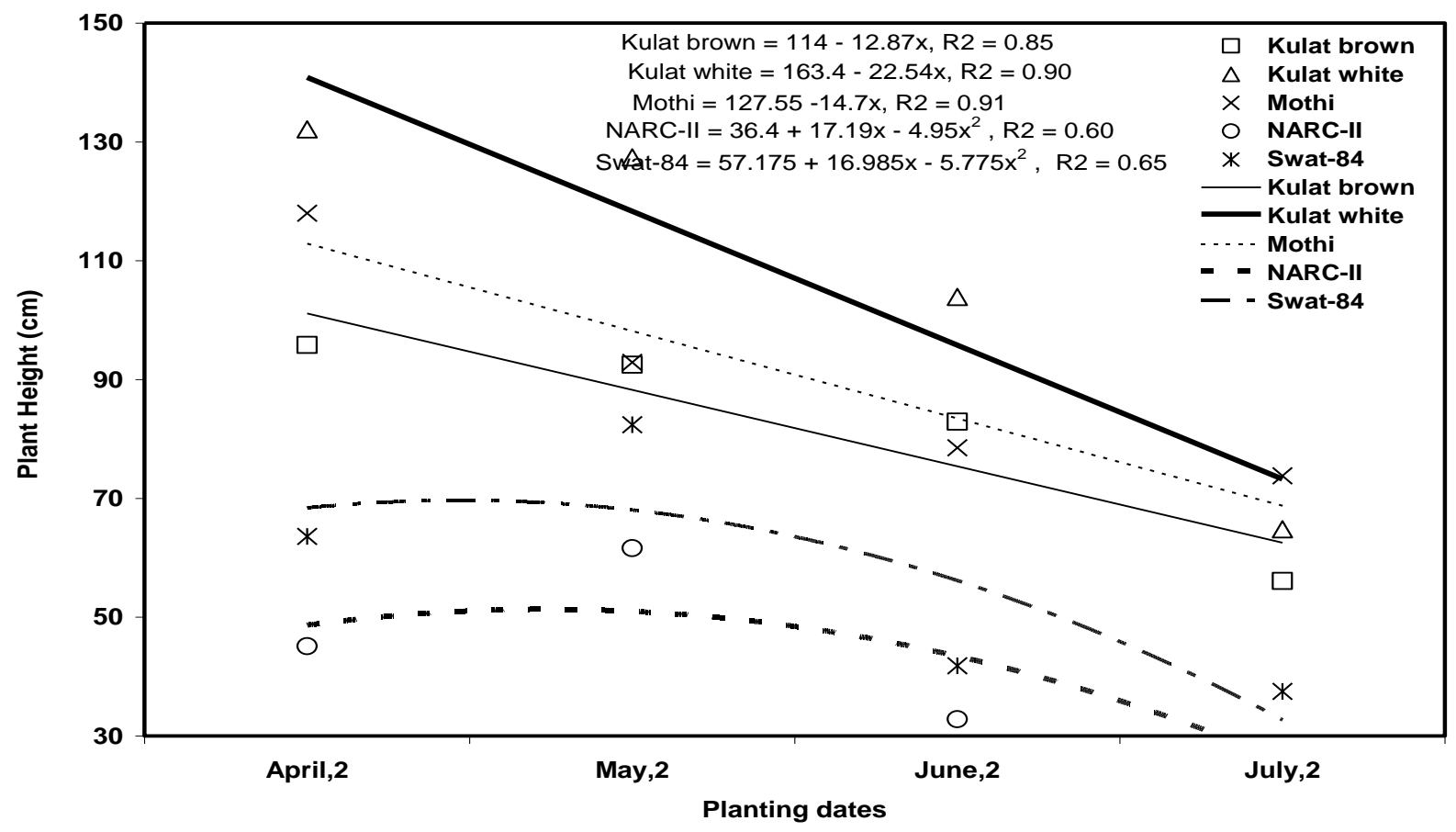

Figure 2. Plant height $(\mathrm{cm})$ of soybean varieties as affected by planting dates

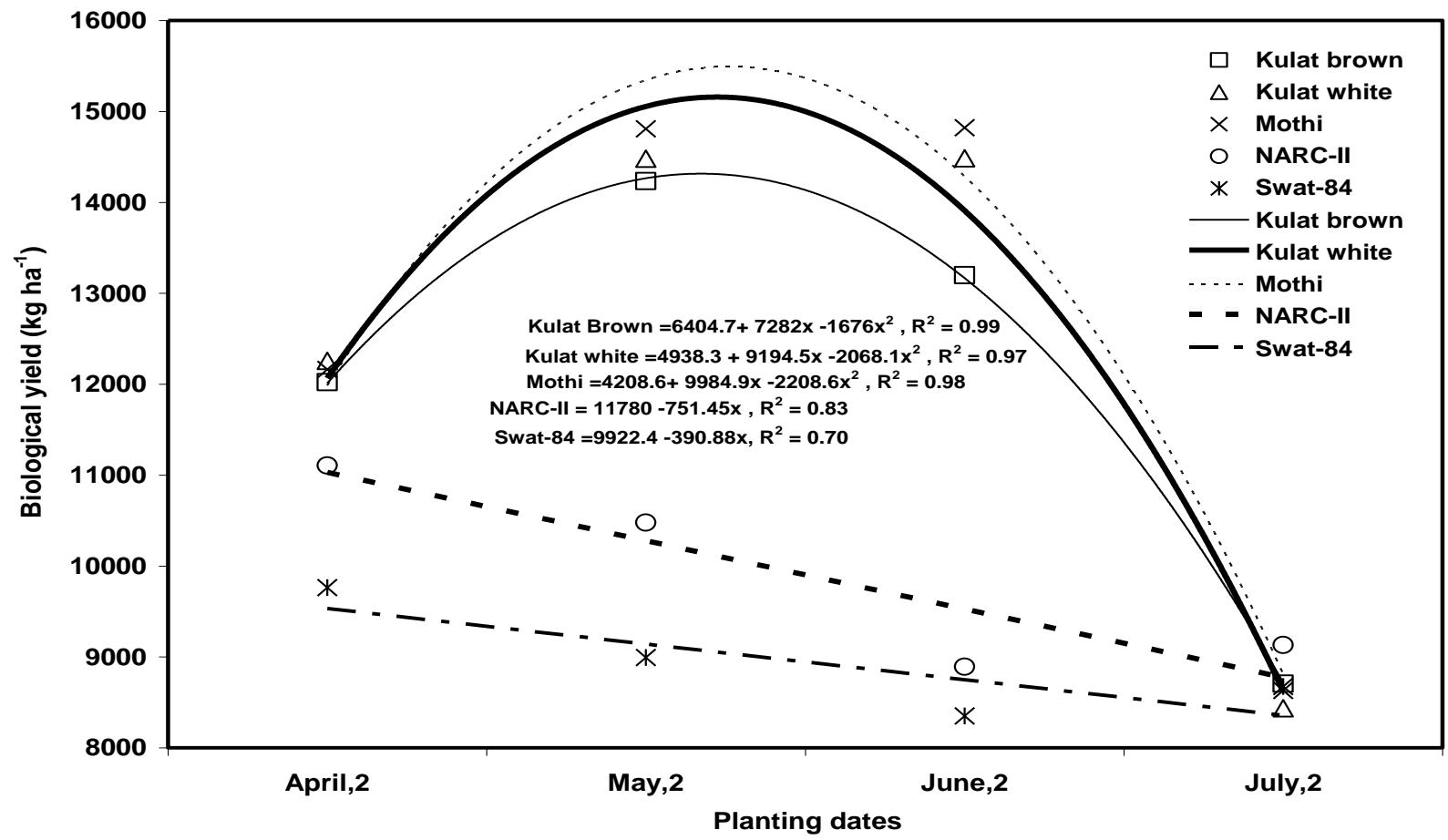

Figure 3. Biological yield $\left(\mathrm{kg} \mathrm{ha}^{-1}\right)$ of soybean varieties as affected by planting dates 
Table 1. Two years means for days to maturity $(\mathrm{R8})$, plant height $(\mathrm{cm})$ and biological yield $\left(\mathrm{kg} \mathrm{ha}^{-1}\right)$ of soybean land races vs improved varieties as affected by planting dates

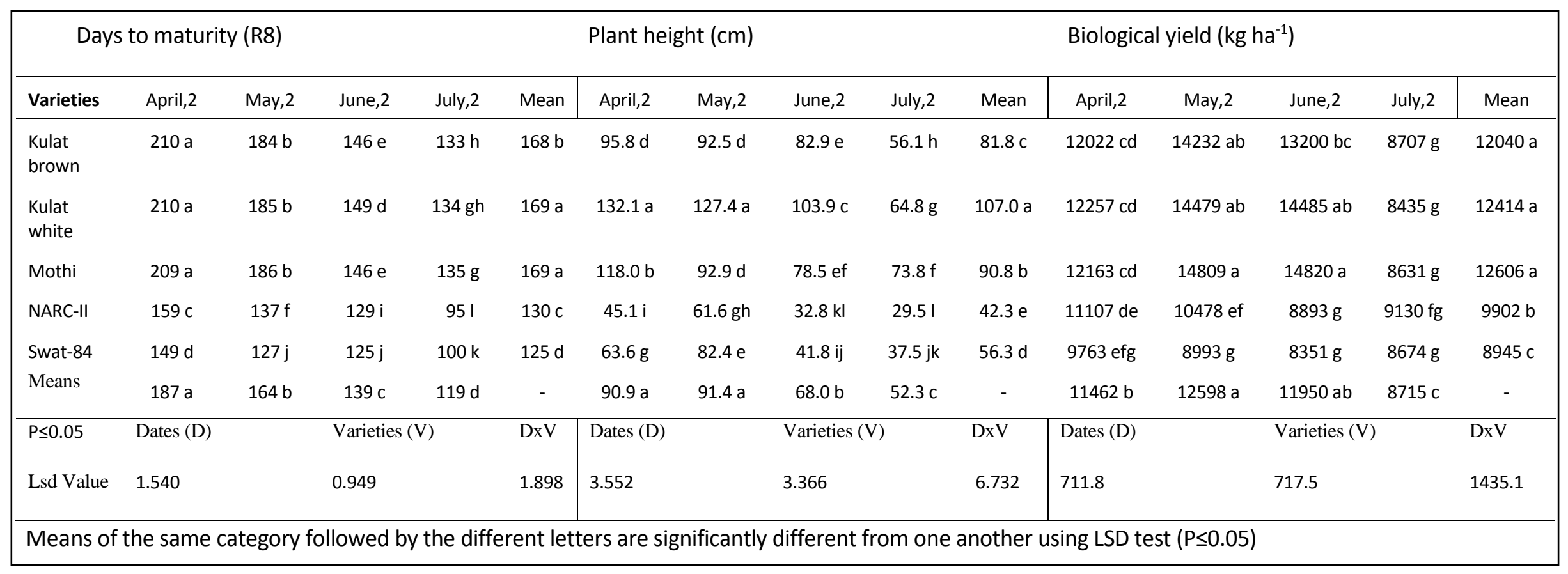


Table 2. Two years means for days to maturity (R8), plant height (cm) and biological yield (kg of soybean land races vs improved varieties as affected by planting dates

\begin{tabular}{|l|c|c|c|}
\hline Soybean varieties & Days to maturity (R8) & Plant height $(\mathrm{cm})$ & Biological yield $\left(\mathrm{kg} \mathrm{ha}^{-1}\right)$ \\
\hline Land races & $169 \mathrm{a}$ & $93.2 \mathrm{a}$ & $62.4 \mathrm{a}$ \\
\hline $\begin{array}{l}\text { Improved } \\
\text { varieties }\end{array}$ & $128 \mathrm{~b}$ & $49.3 \mathrm{~b}$ & $35.0 \mathrm{~b}$ \\
\hline Year-I (2004) & $156 \mathrm{a}$ & $76.9 \mathrm{a}$ & 52.8 \\
\hline Year-II (2005) & $149 \mathrm{~b}$ & $74.4 \mathrm{~b}$ & 50.1 \\
\hline
\end{tabular}

Table 3. Analysis of variance for days to full maturity $(\mathrm{R8})$, plant height $(\mathrm{cm})$ and biological yield $\left(\mathrm{kg} \mathrm{ha}^{-1}\right)$ of soybean varieties as affected by planting dates for two years average

\begin{tabular}{lclll}
\hline S.O.V. & D.F. & Full maturity & Plant height $(\mathbf{c m})$ & Biological yield $\left(\mathbf{k g ~ h a}^{-\mathbf{1}}\right)$ \\
\hline Year (Y) & 1 & $2030.63^{* *}$ & $265.22^{*}$ & $65205.63 \mathrm{~ns}$ \\
Replications (R) & 6 & $11.88 \mathrm{~ns}$ & $34.41 \mathrm{~ns}$ & $1479684.34 \mathrm{~ns}$ \\
Planting dates (D) & 3 & $34959.08^{* *}$ & $14442.14^{* *}$ & $116763349.54 * *$ \\
YxD & 3 & $827.84^{* *}$ & $68.68 \mathrm{~ns}$ & $1910111.88 \mathrm{~ns}$ \\
Error I & 18 & 10.75 & 57.16 & 2295645.76 \\
Varieties (V) & 4 & $16449.76^{* *}$ & $21929.70^{* *}$ & $87394146.50^{* *}$ \\
Land races vs Improved & $(1)$ & $65439.04^{* *}$ & $74096.20^{* *}$ & $329636720.42^{* *}$ \\
YxV & 4 & $324.55^{* *}$ & $294.18^{* *}$ & $617248.38 \mathrm{~ns}$ \\
DxV & 12 & $728.56^{* *}$ & $1010.79^{* *}$ & $18753368.15^{* *}$ \\
YxDxV & 12 & $192.85^{* *}$ & $112.86^{* *}$ & $1597849.85 \mathrm{~ns}$ \\
Error II & 96 & 3.67 & 46.01 & 2101425.41 \\
\hline Total & 159 & & & \\
\hline
\end{tabular}




\section{Results and discussion \\ Days to full maturity (R8)}

Years, planting dates (D), varieties (V) and D $\mathrm{x} V$ significantly affected days to full maturity (Table 1). Full maturity was attained 7 days earlier in 2005 than 2004. Maximum days to full maturity (187) were taken by April planting, while minimum days to full maturity (119) were taken by July planted crop. Full maturity occurred in 164 and 139 days, when planted in May and June respectively. Significant reduction in days to maturity were observed at each successive planting date.

Kulat white and Mothi took maximum days to full maturity (169), followed by Kulat brown which took 168 days to maturity (Table 2). Swat-84 took minimum days in attaining full maturity (125). Improved varieties matured earlier than land races. The overall difference in land races and improved varieties was 41 days.

The interaction between DxV indicated that Kulat brown, Kulat white and Mothi took maximum days to full maturity (210) when planted in April. Days to full maturity decreased when planting was delayed. Similar pattern was observed for NARC-II and Swat84.

Days to maturity clearly indicated that the land races namely Kulat brown, Kulat white and Mothi, late maturing varieties, while improved varieties were short duration, early maturing ones. Land races required 169 days and improved varieties required 128 days to reach maturity. Improved varieties matured 41 days earlier than land races. The proportionate decline in days to maturity was greater in improved varieties than in the land races. Planting date did not affect the calendar date on which full season varieties reach maturity [13]. Decline in days to maturity in soybean of various maturity groups due to delay in planting were well documented [5, 14]. Their results fully support our findings.

\section{Plant height}

Plant height is considered as one of the plant characteristics responsible for providing site for vegetative as well as reproductive organs determining dry matter accumulation. Years, planting dates (D), varieties $(\mathrm{V})$, and $\mathrm{D} \times \mathrm{V}$ interaction significantly affected plant height (Table 1). Soybean planted in 2004 were generally taller than planted in 2005. Maximum plant height $(91.4 \mathrm{~cm})$ was recorded in May planting, while minimum plant height was recorded in July planting. Plant height steadily decreased from $91.4 \mathrm{~cm}$ in May to $52.3 \mathrm{~cm}$ in July planting. After May at each successive planting the reduction was significant. Delay in planting shortened the growing season, which resulted in reduction of plant height as well as other plant characteristics. These findings are in close conformity with the results, that gradual decrease in plant height except May planting [7]. A similar reduction in plant height with late planting was reported $[8,9]$. It was observed no response of plant height to planting dates [11, 14].

Maximum plant height $(107 \mathrm{~cm})$ was recorded for Kulat white followed by Mothi, while minimum plant height $(42.3 \mathrm{~cm})$ was noticed in NARC-II (Table 2). Generally plant height of improved varieties was $50 \%$ less than the height of land races. The interaction between DxV revealed that Kulat white produced tallest plants planted in April and May. Plant height decreased when planting was delayed. Similar pattern was observed for Kulat brown and Mothi. In NARC-II and Swat-84, the plant height increased when planting was advanced from April to May. However, plant height drastically reduced when planting was delayed from May (Fig 2). Height of soybean at maturity was lengthened by a total of $19 \mathrm{~cm}$, when planting was advanced seven weak from mid-June to early May [15].

\section{Biological yield}

Significant variations existed in biological yield, between planting dates (D), varieties 
(V) and $\mathrm{D} x \mathrm{~V}$ interaction for the two years average (Table 3). Biological yield was not affected by years. The highest biological yield $(12598 \mathrm{~kg})$ was produced by May planting followed by June planting and the lowest $(8715 \mathrm{~kg}$ ) by July planting (Table 1). However the biological yield from the April planting was intermediate. Several workers believed that early planted soybeans were efficient producers of biomass and gave higher biomass than late planted ones $[10,11$, 16]. Reduction in biomass by 33, 58 and 76 percent when planting was delayed from June, July and August respectively [9]. Early and late planting is also relative and depends on the actual date of planting. In some cases the first week and last week of the same month are stated early and late, while in other cases planting is stretched over a period of 35 months to be designated as early and late. Maximum biological yield (12606 kg) was given by Mothi followed by Kulat white. Swat-84 produced the minimum biological yield (8945 kg) (Table 2). The average biological yield produced by land races was $23.7 \%$ higher than the improved varieties. Among improved varieties, NARC-II was high yielder of biomass than Swat-84. Long duration soybeans were high biomass producers than short duration soybeans [6, 17].

The interaction between $\mathrm{D} \times \mathrm{V}$ revealed that in Kulat brown, Mothi and Kulat white the biological yield increased when planting was advanced from April to May and June and then drastically declined in July. In NARC-II and Swat-84, biological yield decreased when planting was delayed from April to July (Fig $3)$. Biological yield of land races decreased by $16.5 \%$ when planted earlier than May and by 2.3 and $40.9 \%$ when delayed from May to June and July respectively. In improved varieties the biological yield was highest in April planting and decreased by 6.7, 17.3 and $14.6 \%$ when delayed to May, June and July respectively.
Statistically, the biological yield produced by May and June planting was greater and similar, which could be attributed to higher plant height, leaf area and crop growth rate (CGR). The lowest biological yield from July planting may be due to low plant height, leaf area and particularly low crop growth rate. Biological yield from April planting inspite of similar plant height, and greater leaf area was relatively less than May and June planting. The only reason could be the lower crop growth rate due to low temperatures in the month of April (Fig.1). The higher biomass production of land races was because of greater plant height, leaf area, CGR and RGR as compared with improved varieties.

\section{Conclusion}

It is concluded that delaying planting dates from April to July decreased days to maturity, plant height and biological yield. Land races took maximum days to maturity, biological yield, and plant height as compared to improved varieties. During second year of soybean cultivation crop mature earlier but short plants and minimum biological yield as compared to first year of cultivation.

\section{Authors' contributions}

Performed \& designed the experiments: A Muhammad \& SK Khalil, Analyzed the data: AZ Khan, Contributed reagents \& Reference section: N Ahmad

\section{References}

1. Duncan WG (1986). Planting patterns and soybean yields. Crop Sci 26: 584588

2. Shibles RM, \& Weber CR (1966). Interception of solar radiation and dry matter production by various soybean planting patterns. Crop Scie 6: 55-59.

3. Beuerlein JE, Pendleton JW, Bauer ME, \& Ghorashy SR (1971). Effect of branch removal and plant population at equidistant spacing on yield and light use effiency of 
soybean canopies. Agron J 63: $317-$ 319

4. Rocha VS, Oliveira AB, Sediyama T, Gomes JLL, Sedeyama CS, \& Pereira MG (1966). Aqualidode da sementa de soja. Vicosa: UFV. Boletin 188: 76.

5. Board JE (1985). Yield components associated with soybean yield reduction at non-optimal planting dates. Agron J 77: 135-140

6. Hatam M \& GH Jamro (1990). Date of planting influencing cumulative dry matter yield in three soybean cultivars. Pak Phyton 2: 13-18

7. Beatty KD, Eldridge IL \& Simpson AM (1982). Soybean response to different planting patterns and dates. Agron J 74: 859-862.

8. Parvez AQ, Gardner FP \& Boote KJ (1989). Determinate and indeterminate type soybean cultivar responses to pattern, density and planting date. Crop Sci 29: 150-157.

9. Khan AZ (2001). Influence of planting date and plant density on canopy temperature, seed development, seed quality and yield of soybean. Ph.D Dissertation, University of Agriculture, Faisalabad.

10. Shah P (1988). Growth curve analysis for soybean cultivars. Ph.D Dissertation, University of Illinois, Urbana, USA.
11. Pedersen P \& Lauer JG (2004). Soybean growth and development in various management systems and planting dates. Crop Sci 44: 508-515

12. Steel RGD \& Torrie JH (1984). Principles and procedures of statistics. 2nd Ed. P.172-177. McGraw Hill Book Co. Singapore.

13. Scott WO \& Aldrich SR (1983). Planting and cropping systems. In: Modern soybean production, Second Ed. S and A publications Inc. Champain ILL. USA pp.83-86.

14. Elmore RW (1990). Soybean cultivar response to tillage systems and planting date. Agron J 82: 69-73

15. Bastidas AM, Setiyono TD, Dobermann A, Cassman KG, Elmore RW, Graef GL \& Specht JE (2008). Soybean Sowing Date: The Vegetative, Reproductive, and Agronomic Impacts. Crop Sci 48: 727-740

16. Hatam M \& Jamro GH (1993). Effect of planting date on developmental phases in determinate and indeterminate soybean cultivars. Pak J Sci 36: 314-317

17. Khan AZ, Shah P, Khalil SK \& Ahmad B (2004). Yield of soybean cultivars as affected by planting date under Peshawar valley conditions. The Nucleus 41: 93-95. 